Савенко Ігор Іванович доктор економічних наук, професор, завідувач кафедри менеджменту і логістики Одеської національної академії харчових технологій, м. вул. Канатна, 112, Одеса, 65039, тел.: (048) 712-41-33, e-mail: IISavenko52@ukr.net, https://orcid.org/0000-0001-7901-6360

Седікова Ірина Олександрівна доктор економічних наук, професор кафедри менеджменту і логістики Одеської національної академії харчових технологій, вул. Канатна, 112, м. Одеса, 65039, тел.: (048) 712-41-14, e-mail: irinasedikova@ukr/net, https://orcid.org/0000-0001-5684-6927

\title{
ПІДХОДИ ЩОДО УДОСКОНАЛЕННЯ ПРОЦЕСУ УПРАВЛІННЯ АНТИКРИЗОВОЮ СТРАТЕГІЄЮ ПІДПРИЕМСТВ КОНДИТЕРСЬКОЇ ГАЛУЗІ
}

Анотація. Розв'язання проблеми розробки комплексної програми антикризового управління підприємством є основою вирішення проблем слабкого стратегічного планування, у частині тактичних заходів, попереджання та прогнозування змін в нестабільному середовищі, виявлення диспропорції всередині підприємства. У даному досліджені розроблено пропозиції щодо антикризового управління підприємства кондитерської галузі в умовах нестабільного економічного середовища.

Доведено, що економіці поняття антикризового управління $є$ не новим, однак все ще дискусійним, що викликає велику кількість суперечностей та тлумачень серед науковців, у закордонній літературі дане поняття довгий період часу розглядалось як зовнішне управління, що має здійснюватись спеціально підготовленими фахівцями і доцільно тільки на підприємствах, банкрутство яких має негативні суспільні наслідки. Критичний аналіз авторських визначень поняття «антикризове управління» дав змогу виокремити підходи до розуміння його сутності та зроблено його систематизацію.

Здійснено аналіз та виявлено тенденції розвитку українського ринку кондитерських виробів, встановлено основні фактори негативного впливу на ринок, а саме, девальвація гривні, падіння купівельної спроможності населення, військовий конфлікт на сході України, а також закриття традиційних ринків збуту в країнах - членах СНД. Встановлено, що ринок кондитерських виробів України $\epsilon$ висококонцентрованим. 
Задля визначення кризового стану підприємств кондитерської галузі, проведено експрес-діагностику фінансового стану підприємства на прикладі ПрАТ «Київська кондитерська фабрика «Рошен». Визначено, що за показниками останнього звітного року ПрАТ «Київська кондитерська фабрика «Рошен» суттєво зменшила розвиток кризових явищ, однак ймовірність погіршення існуючої ситуації висока. Для проведення дослідження було обрано метод дискрімінатного аналізу.

В межах помірної політики оптимізації дебіторської заборгованості антикризової стратегії ПрАТ «Київська кондитерська фабрика «Рошен» запропоновано використання факторингу, який надасть можливість без зміни договірних термінів оплати зменшити суму дебіторської заборгованості підприємства на 70 \% без зміни періоду інкасації в договірних умовах 3 контрагентами.

Ключові слова: антикризове управління, підприємства кондитерської галузі, стратегія, фінансова незалежність, банкрутство, стійкість.

Savenko Ihgor Ivanovich Doctor of Economics, Professor, Head of the Department of Management and Logistics of the Odessa National Academy of Food Technologies, Kanatna St., 112, Odessa, 65039, tel.: (048) 712-41-33, e-mail: IISavenko52@ukr.net, https: // orcid.org / 0000-0001-7901-6360

Sedikova Iryna Oleksandrivna Doctor of Economics, Professor of the Department of Management and Logistics of the Odessa National Academy of Food Technologies, Kanatna St., 112, Odessa, 65039, tel.: (048) 712-41-14, e-mail: irinasedikova@ukr / net, https // orcid.org / 0000-0001-5684-6927

\section{APPROACHES TO IMPROVING THE PROCESS OF ANTI-CRISIS STRATEGY MANAGEMENT OF CONFECTIONERY ENTERPRISES}

Abstract. Solving the problem of developing a comprehensive program of crisis management of the enterprise is the basis for solving the problems of weak strategic planning, in terms of tactical measures, prevention and forecasting of changes in an unstable environment, detection of imbalances within the enterprise. In this study, proposals for crisis management of the confectionery industry in an unstable economic environment.

It is proved that the concept of crisis management is not new to the economy, but still debatable, which causes a lot of contradictions and interpretations among scientists, in the foreign literature this concept has long been considered as external management, which should be carried out by specially trained specialists and appropriate only in 
enterprises, bankruptcy of which has negative social consequences. Critical analysis of the author's definitions of the concept of «crisis management» made it possible to distinguish approaches to understanding its essence and made its systematization.

The analysis and trends of the Ukrainian confectionery market are identified, the main factors of negative impact on the market, namely, the devaluation of the hryvnia, falling purchasing power, the military conflict in eastern Ukraine, and the closure of traditional markets in CIS countries. It is established that the confectionery market of Ukraine is highly concentrated.

In order to determine the crisis state of the confectionery industry, rapid diagnostics of the financial condition of the enterprise was carried out on the example of PJSC «Kyiv Confectionery Roshen». It is determined that according to the indicators of the last reporting year, PJSC Kyiv Confectionery Factory «Roshen» has significantly reduced the development of crisis phenomena, but the probability of deterioration of the current situation is high. The method of discriminant analysis was chosen for the study. As part of a moderate policy to optimize receivables of the anti-crisis strategy of PJSC «Kyiv Confectionery Roshen» proposed the use of factoring, which will allow without changing the contractual payment terms to reduce the amount of receivables by $70 \%$ without changing the collection period in contractual terms with contractors.

Keywords: crisis management, confectionery enterprises, strategy, financial independence, bankruptcy, sustainability.

Постановка проблеми. Сучасні умови господарювання дали змогу підприємствам отримати тільки позитивні результати діяльності, але і призвели до того, що більшість вітчизняних підприємств, внаслідок загальноекономічної кризи, опинилися на межі банкрутства. Головними причинами такої ситуації $€$ слабке стратегічне планування, у частині тактичних заходів, що є базисом задля попереджання та прогнозування змін в нестабільному середовищі, виявлення диспропорції всередині підприємства і неможливість швидкого реагування. За таких умов постає проблема розробки комплексної програми антикризового управління підприємством.

Аналіз останніх досліджень i публікацій. Проблема антикризового управління управления $€$ об'єктом дослідження багатьох науковців, як: Л. Лігоненка, О. Терещенка, Є. Уткіна, Л. Ситника, І. Бланка, В. Василенка, В. Рубан, К. Хамфріс, Б. ІІаттерсон, Г. Спрінгейт, Е. Альтман, Г. Тішоу, Р. Ліс та ін.

Мета статті. Метою статті $є$ розробка пропозицій антикризового управління підприємства кондитерської галузі в умовах нестабільного економічного середовища.

Виклад основного матеріалу. Сучасні ринкові умови диктують жорсткі правила не тільки входження, але і функціонування підприємств у своєму 
сегменті. Підтвердженням цьому є кризовий стан більшості українських суб'єктів господарюванням, серед яких не виключенням $є$ кондитерська галузь. За таких умов для підприємств особливо актуальним стає питання вибору стратегії антикризового управління для стабілізації та подальшого покращення їх мікроекономічного стану.

В економіці поняття антикризового управління є не новим, однак все ще дискусійним, що породжує велику кількість суперечностей та тлумачень серед науковців. Антикризове управління у закордонній літературі довгий період часу розглядалось як зовнішнє управління, що має здійснюватись спеціально підготовленими фахівцями і доцільно тільки на підприємствах, банкрутство яких має негативні суспільні наслідки [1]. Аналіз наукової літератури свідчить, що значна кількість вчених під антикризовим управлінням розуміє «безпосередні дії, які спрямовані на запобігання появі та розвитку кризи підприємства» [2]. Критичний аналіз авторських визначень поняття «антикризове управління» дає можливість виокремити підходи до розуміння його сутності [2] (див. рис. 1).

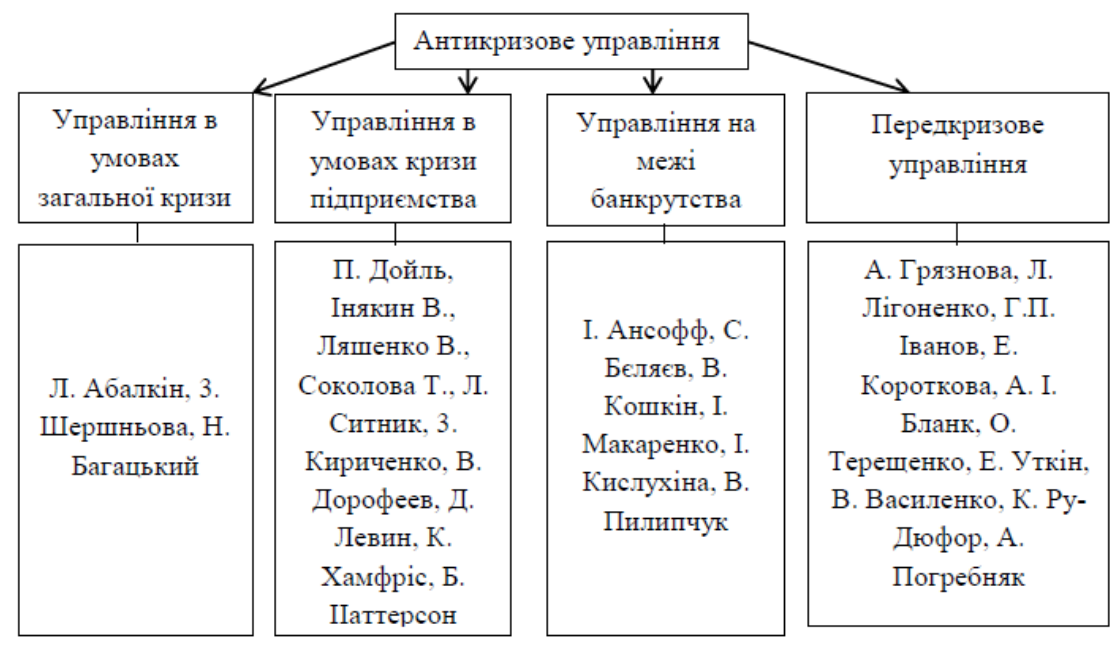

Рис. 1. Наукові підходи до тлумачення поняття «антикризове управління» Джерело: узагальнено авторами на основі [3, 4, 5, 6]

Так, одні вчені антикризове управління розглядають як управління підприємством в умовах загального кризового стану економіки, інші ж розділяють думку про те, що це управління підприємством, яке безпосередньо перебуває на межі банкрутства; треті ж визначають дане поняття як управління підприємством в умовах кризи; останні ототожнюють категорію антикризового управління із заходами для запобігання появі кризових явищ в діяльності суб'єкта господарювання [2].

У жорстких, нестабільних умовах господарювання, підприємства кондитерської галузі шукають нові стратегії розвитку, напрями та засоби розвитку інноваційної діяльності. За результатами літературного огляду ми пропонуємо поділити напрями інноваційної діяльності підприємств кондитерської галузі на 
такі типи: техніко-технологічні, які пов’язані з продукцією, що виробляється, впровадженням нових рішень у виробництво та технологіями; організаційні, які покликані змінювати систему управління та організацію процесу створення продукції або послуг [7]. За останні роки український кондитерський ринок зазнав значних змін. За словами Олександра Соколова, генерального директора компанії Pro-Consulting «... основними факторами негативного впливу на ринок були девальвація гривні, падіння купівельної спроможності населення, військовий конфлікт на сході України, а також закриття традиційних ринків збуту в країнах членах СНД» [7].

Ринок кондитерських виробів України є висококонцентрованим. Основними гравцями на українському ринку є: ПрАТ «Київська кондитерська фабрика «Рошен», Корпорація «Бісквіт-шоколад», ТОВ «Шоколадна компанія «МиР», ТОВ «Шоколадна компанія «МиР», ПрАТ «Кондитерська Фабрика «АВК» м. Дніпро», ПАТ «Конті», ПрАТ «Монделіс Україна», ПАТ «Львівська Кондитерська Фабрика «Світоч», ЗАТ «Житомирські ласощі», ПАТ «Полтавокондитер» (див. рис. 2).

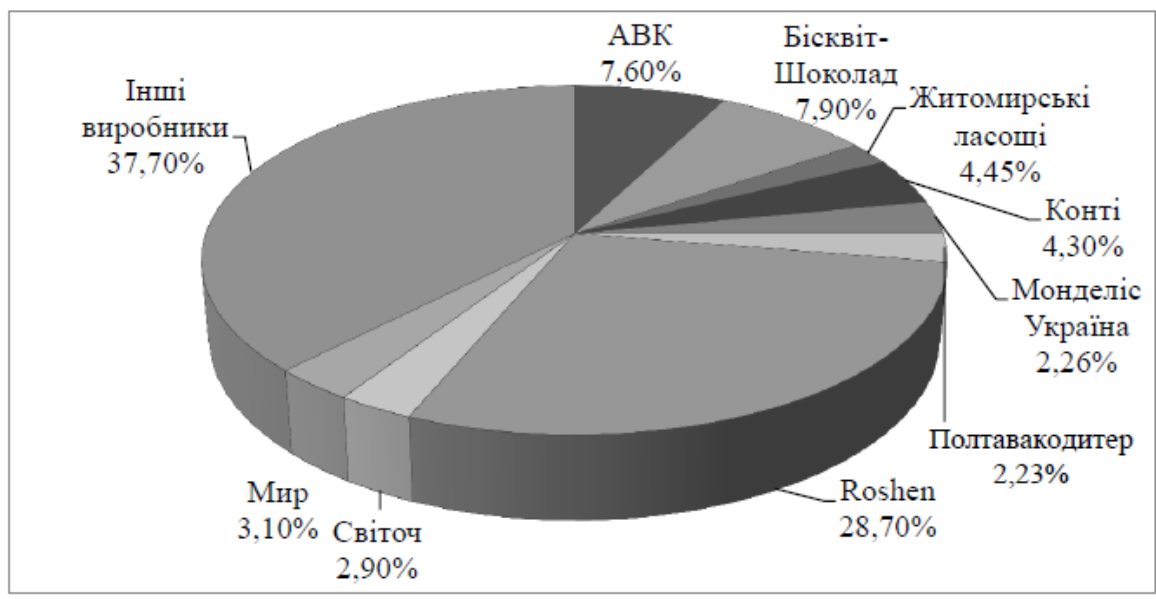

Рис. 2. Розподіл часток між учасниками кондитерського ринку Украӥни

$$
\text { y } 2019 \text { p., \% [8] }
$$

Надалі, для визначення кризового стану підприємств кондитерської галузі, проведемо експрес-діагностику фінансового стану підприємства на прикладі ПрАТ «Київська кондитерська фабрика «Рошен». Протягом звітного періоду, підприємство знаходиться в стані легкої кризи, адже наявні короткочасні симптоми кризи, що проявляється в динаміці фінансової незалежності та результативності діяльності, ліквідності та ділової активності. Протягом 20172019 років мало місце застосування використання стабілізаційної стратегії антикризового управління, що підтверджується динамікою отриманих результуючих коефіцієнтів. За показниками останнього звітного року ПрАТ «Київська кондитерська фабрика «Рошен» суттєво зменшила розвиток кризових 
явищ, однак ймовірність погіршення існуючої ситуації висока. Для проведення дослідження було обрано метод дискрімінатного аналізу (див. табл. 1).

Таблиия 1

Оцінка ефективності управління антикризовою стратегією ПрАТ «Київська кондитерська фабрика «Рошен» за моделлю О. Терещенка

\begin{tabular}{|l|c|c|c|c|c|}
\hline \multicolumn{1}{|c|}{ Показники } & 2016 & 2017 & 2018 & 2019 & 2020 \\
\hline саshflow/зобов'язання & $-0,0001$ & 0,0001 & 0,0010 & $-0,0007$ & 0,0258 \\
\hline валюта балансу/зобов'язання & 2,456 & 2,961 & 4,037 & 5,321 & 3,102 \\
\hline прибуток/валюта балансу & 0,005 & 0,044 & 0,016 & 0,006 & 0,003 \\
\hline прибуток/виручка від реалізації & 0,008 & 0,118 & 0,044 & 0,017 & 0,011 \\
\hline $\begin{array}{l}\text { виробничі запаси/виручка від } \\
\text { реалізації }\end{array}$ & 0,015 & 0,030 & 0,034 & 0,038 & 0,031 \\
\hline $\begin{array}{l}\text { виручка від реалізації/валюта } \\
\text { балансу }\end{array}$ & 0,608 & 0,375 & 0,355 & 0,353 & 0,326 \\
\hline \multicolumn{1}{|c|}{$Z_{\text {Й }}$} & 0,35 & 1,32 & 0,75 & 0,62 & 0,42 \\
\hline Ймовірність банкрутства & $\begin{array}{c}\text { Загроза } \\
\text { банкрутст } \\
\text { ва }\end{array}$ & $\begin{array}{c}\text { Фінансова } \\
\text { стійкість } \\
\text { порушена }\end{array}$ & $\begin{array}{c}\text { Загроза } \\
\text { ства }\end{array}$ & $\begin{array}{c}\text { Загроза } \\
\text { банкрут } \\
\text { ства }\end{array}$ & $\begin{array}{c}\text { багронкрутст } \\
\text { ва }\end{array}$ \\
\hline
\end{tabular}

Джерело: складено автором на основі розрахунків

Згідно результатів експрес-діагностики, зроблено висновок про використання підприємством стабілізаційної стратегії. Ефективні результати стратегія дала в останній звітній період, адже майже всі показники знаходяться у межах норми.

Враховуючи можливі напрями, тип та глибину кризи, стадію життєвого циклу та можливості підприємства в межах стратегії стабілізації, ПрАТ «Київська кондитерська фабрика «Рошен» перспективним є застосування заходів щодо оптимізації процесу управління дебіторською заборгованістю, а також удосконалення маркетингової політики. Застосування антикризових заходів в межах даних напрямів має за мету усунення проблемних аспектів діяльності підприємства, виявлених в ході фінансового, дискримінатного аналізу та експресдіагностики. В межах заходів удосконалення ефективності управління антикризовою стратегією ПрАТ «Київська кондитерська фабрика «Рошен» запропоновано орієнтуватись на оптимізацію управління дебіторською заборгованістю. Управління дебіторською заборгованістю має стратегічний характер, адже процес збільшення дебетового сальдо балансу паралельно 3 погіршенням ситуації із пораненням боргів може призвести до зменшення кількості готівкових коштів, а також здійснювати тиск на грошові потоки підприємства. Для уникнення ймовірності виникнення такого стану потребує удосконалення процес планування, організації та контролю дебіторської 
заборгованості з метою забезпечення ii керованості та недопущення додаткових ризиків. Зважаючи на те, що ефективність управління дебіторською заборгованістю безпосередньо впливає на прибутковість підприємства, визначає дисконтну і кредитну політику для покупців, здійснимо більш детальний розгляд дебіторської заборгованості ПрАТ «Київська кондитерська фабрика «Рошен» (див. табл. 2).

Таблиця 2

\section{Дебіторська заборгованість ПрАТ «Київська кондитерська фабрика} «Рошен», 2016-2019 рр.

\begin{tabular}{|c|c|c|c|c|c|}
\hline Найменування показника & 2016 & 2017 & 2018 & 2019 & 2020 \\
\hline $\begin{array}{l}\text { Дебіторська заборгованість за продукцію, } \\
\text { товари, роботи, послуги }\end{array}$ & 49016 & 67067 & 92001 & 71252 & 51544 \\
\hline $\begin{array}{l}\text { Дебіторська заборгованість за } \\
\text { розрахунками: } \\
\text { за виданими авансами }\end{array}$ & 0 & 0 & 0 & 0 & 0 \\
\hline з бюджетом & 0 & 2772 & 0 & 0 & 2951 \\
\hline Інша поточна дебіторська заборгованість & 4144 & 454 & 1279 & 2388 & 23330 \\
\hline
\end{tabular}

Джерело: розраховано за даними підприємства

Як бачимо із таблиці в структурі дебіторської заборгованості підприємства в останньому звітному періоді валову частку займає торговельна дебіторська заборгованість, за розрахунками 3 бюджетом та інша поточна дебіторські заборгованості. Дебіторська заборгованість за розрахунками з бюджетом не має перманентний характер. Проаналізуємо питому вагу дебіторської заборгованості в загальній сумі оборотних активів підприємства, а також визначимо питому вагу iї основних видів (табл. 3).

Таблиця 3

Питома вага дебіторської заборгованості в оборотних активах ПрАТ «Київська кондитерська фабрика «Рошен», 2016-2018 рр.

\begin{tabular}{|c|c|c|c|c|c|}
\hline Роки & Оборотні & Питома вага & \multicolumn{2}{|c|}{ Питома вага в дебіторській заборгованості, \% } \\
\cline { 4 - 6 } & активи, & дебіторської & заборгованості & заборгованості & інша \\
тис. грн. & $\begin{array}{c}\text { заборгованості } \\
\text { в оборотних } \\
\text { активах, } \%\end{array}$ & $\begin{array}{c}\text { за товари, } \\
\text { послуги }\end{array}$ & $\begin{array}{c}\text { поточна } \\
\text { розрахунками } \\
\text { з бюджетом }\end{array}$ & заборгованість \\
\hline 2016 & 60636 & 88 & 92 & 0 & 8 \\
\hline 2017 & 79236 & 89 & 95 & 4 & 1 \\
\hline 2018 & 102044 & 91 & 99 & 0 & 3 \\
\hline 2019 & 82630 & 89 & 97 & 4 & 30 \\
\hline 2020 & 92601 & 84 & 66 & 0 & 1 \\
\hline
\end{tabular}

Джерело: розраховано за даними підприємства 
Таким чином, бачимо, що питома вага загальної суми дебіторської заборгованості протягом років в оборотних активах коливалась в межах 84-91 \%, що свідчить про те, що підприємству необхідно змінювати політику кредитування своїх клієнтів. На таку динаміку могли вплинути наступні фактори: низька платоспроможність клієнтів, недотримання платіжної дисципліни, а також прорахунки підприємства в політиці взаємодії з дебіторами. Однак в останньому звітному році ситуація змінилась: торговельна дебіторська заборгованість зменшилась на 31\%, однак суттєво зросла частка іншої поточної заборгованості ( $3 \%$ до $30 \%$ ).

Враховуючи отриманні результати, в рамках стабілізаційної стратегії для ПрАТ «Київська кондитерська фабрика «Рошен» за цільові орієнтири запропоновано два сценарії: консервативна політика - досягнення галузевих граничних значень оборотності та терміну погашення дебіторської заборгованості як основних показників ефективності управління дебіторською заборгованістю; помірна - як виявлення раціонального 3 позицій інтересів підприємства та контрагентів періоду інкасації заборгованості. Реалізація консервативної політики передбачає застосування тих заходів, що дозволять скоротити період інкасації дебіторської заборгованості до 45 днів та збільшити кількість обертів до 8. При застосуванні даного комплексу заходів в стратегічній перспективі передбачається зменшення дебіторської на 20 \%. В той же час, варто вказати, що особливістю кондитерської галузі $\epsilon$ жорстка конкуренція, яка вимагає використання широко спектру заходів конкурентної боротьби, у т.ч. і шляхом застосування більш м'якої політики кредитування контрагентів. Зокрема, такі висновки дозволяє зробити порівняння показників ефективності управління дебіторською заборгованістю конкурентів підприємства бази апробації (ПрАТ «Кондитерська Фабрика «АВК» м. Дніпро» та ПАТ «Львівська Кондитерська Фабрика «Світоч») (табл. 4).

Таблиичя 4

Порівняння показників управління дебіторською заборгованістю конкурентів ПрАТ «Київська кондитерська фабрика «Рошен»

\begin{tabular}{|l|c|c|c|c|}
\hline \multicolumn{2}{|c|}{ ПрАТ «Кондитерська Фабрика «АВК» } & 2016 & 2017 & 2019 \\
\hline $\begin{array}{l}\text { Середньорічна дебіторська } \\
\text { заборгованість, тис. грн. }\end{array}$ & 110438,5 & 189391,5 & 271165 & 318493, \\
\hline Період погашення, дні & 128 & 157 & 119 & 128 \\
\hline $\begin{array}{l}\text { Частка дебіторської заборгованості у } \\
\text { виручці }\end{array}$ & 0,36 & 0,44 & 0,33 & 0,35 \\
\hline $\begin{array}{l}\text { Коефіціснт оборотності дебіторської } \\
\text { заборгованості }\end{array}$ & 2,81 & 2,29 & 3,03 & 2,82 \\
\hline
\end{tabular}




\begin{tabular}{|l|c|c|c|c|}
\hline \multicolumn{4}{|c|}{ ПАТ «Львівська Кондитерська Фабрика «Світоч» } \\
\hline $\begin{array}{l}\text { Середньорічна дебіторська } \\
\text { заборгованість, тис. грн. }\end{array}$ & 82937 & 285712,5 & 546314 & 604445, \\
\hline Період погашення, дні & 22 & 44 & 86 & 94 \\
\hline $\begin{array}{l}\text { Частка дебіторської заборгованості у } \\
\text { виручці }\end{array}$ & 0,06 & 0,12 & 0,24 & 0,26 \\
\hline $\begin{array}{l}\text { Коефіцієнт оборотності дебіторської } \\
\text { заборгованості }\end{array}$ & 16 & 9 & 4 & 3,8 \\
\hline
\end{tabular}

Джерело: розраховано за даними підприємства

Як видно із табл. 4, наразі конкуренти не досягають нормативів галузі серед показників управління дебіторською заборгованістю. Однак ПАТ «Львівська Кондитерська Фабрика «Світоч» в своїй діяльності використовувала більш жорстку політику щодо роботи 3 дебіторами, завдяки якій підприємство виходило на нормативні значення оборотності та періоду погашення. Спад ефективності управління дебіторською заборгованістю даного суб'єкта господарювання пояснюється впливом зовнішніх факторів та переходом на більш помірну політику. ПрАТ «Київська кондитерська фабрика «Рошен» пропонується використання факторингу, який надасть можливість без зміни договірних термінів оплати зменшити суму дебіторської заборгованості підприємства. Запровадження даного інструменту, враховуючи його результативність, пропонується на середньострокову перспективу. Для факторингового фінансування рекомендовано використовувати банківську послугу АT «Укрсоцбанк». Дебіторська заборгованість ПрАТ «Київська кондитерська фабрика «Рошен» на кінець 2019 року становила 77825 грн., оборотність - 3,42, період інкасації - 105 днів. Згідно договору факторингу резерв сумнівних боргів становить 30 \%, аванс підприємству - 70 \%, разова комісія банку при видачі авансу - 3,5 \%, ставка банку на операцію факторингу - $21 \%$. Розрахунок доходів від впровадження даного заходу та наведено в табл. 5.

Таблиия 5

Доходи від впровадження факторингу на ПрАТ «Київська кондитерська фабрика «Рошен»

\begin{tabular}{|l|c|}
\hline \multicolumn{1}{|c|}{ Показник } & $\begin{array}{c}\text { Результат, тис. } \\
\text { грн. }\end{array}$ \\
\hline Дебіторська заборгованість & 77825 \\
\hline Резерв сумнівних боргів & 23348 \\
\hline Комісія & 2724 \\
\hline Дохід до сплати відсотків & 51754 \\
\hline Оплата відсотків факторингу & 3175 \\
\hline Загальна сума доходу від факторингу & 48578 \\
\hline Загальна вартість оплати факторингу (вартість операційного циклу) & 5899 \\
\hline Повна вартість використання факторингу & 20191 \\
\hline Ефективність факторингу, \% & $41,6 \%$ \\
\hline
\end{tabular}

Джерело: складено авторами на основі розрахунків 
Отже, для використання банківської послуги факторингу в рамках управління дебіторською заборгованістю підприємство має виділити 20191 тис. грн., при цьому ефективність такого вкладу оцінена в 41,6 \%.

Висновки. Таким чином, запропоновані заходи дозволять ПрАТ «Київська кондитерська фабрика «Рошен» зменшити дебіторську заборгованість на 70 \% без зміни періоду інкасації в договірних умовах 3 контрагентами. Завдяки даному інструменту м’якої політики, підвищиться оборотність дебіторської заборгованості до 6,08 оборотів та зменшиться період повернення дебіторської заборгованості до 59 днів, і як наслідок, покращаться показники ефективності управління дебіторською заборгованістю. Також пришвидшиться оборотність оборотних активів на 59,1 \% та зменшиться період їх оборотності на 37,3 \%. Підприємство зможе одержати дохід в сумі 48578 тис. грн., тобто збільшити суму чистого доходу на 18,7 \%. При цьому за рахунок використання даної системи ПрАТ «Київська кондитерська фабрика «Рошен» зможе зменшити частку дебіторської заборгованості у чистому доході на 43,7 \% та отримувати на $111,1 \%$ більше чистого доходу.

\section{Лimepamypa:}

1. Лігоненко Л. О. Антикризове управління підприємством: підручник. К.: Київ. нац. торг.-екон. ун-т, 2005.824 с.

2. Коляденко I. І. Наукові підходи до сутності антикризового управління. Бізнес-навігатор. 2018. № 2-2 (45). С. 7-10.

3. Бабіна Н. О. Антикризовий фінансовий контролінг як фактор забезпечення економічної безпеки підприємства. Ефективна економіка. № $5.2014 . \quad$ URL : http://www.economy.nayka.com.ua/?op=1\&z=3018 (дата звернення 22.12.2020).

4. Глєбова А. О. Формування системи антикризового управління на підприємстві. Молодий вчений. 2015. № 11(2). С. 35-40.

5. Піюренко I. О. Основні теоретичні концепції антикризового управління підприємством. Бізнес-навігатор. 2012. № 3. С. 173-178.

6. Романяк Г. М. Сутність антикризового управління підприємством в умовах нестабільного ринкового середовища. URL: http://nbuv.gov.ua/UJRN/Nz_2016_1_31 (дата звернення 25.12.2020).

7. Седікова I. О. Управління інноваційною діяльністю підприємств кондитерської галузі. Наук вісн. Ужгородського нац. ун-ту. Серія Міжнародні економічні відносини та світове господарство. 2018. Вип. 18, Ч. 3. С. 55 - 59.

8. Інформаційний портал «Ліга.net» URL: https://www.liga.net/economics/infografica/kakizmenilas-rasstanovka-sil-na-konditerskom-rynke-ukrainy (дата звернення 27.12.2020).

\section{References:}

1. Ligonenko L. O. (2005). Antykryzove upravlinnya pidpryyemstvom: pidruchnyk [Anti-crisis management of the enterprise: a textbook]. Kyiv: Kyiv National University of Trade and Economics. p. 824. [in Ukrainian]. 
2. Kolyadenko I. I. (2018). Naukovi pidxody do sutnosti antykryzovogo upravlinnya [Scientific approaches to the essence of crisis management]. Biznes-navigator. Vol. 2-2 (45). p. 7-10. [in Ukrainian].

3. Babina N. O. (2014) Antykryzovyj finansovyj kontroling yak faktor zabezpechennya ekonomichnoyi bezpeky pidpryyemstva [Anti-crisis financial controlling as a factor in ensuring the economic security of the enterprise]. economy.nayka.com.ua. Retrieved from: http://www.economy.nayka.com.ua [in Ukrainian].

4. Glyebova A. O. (2015). Formuvannya systemy antykryzovogo upravlinnya na pidpryyemstvi. [Formation of anti-crisis management system at the enterprise] Molodyj vchenyj. Vol. 11(2). p. 35-40. [in Ukrainian].

5. Piyurenko I. O. (2012). Osnovni teoretychni koncepciyi antykryzovogo upravlinnya pidpryyemstvom [Basic theoretical concepts of crisis management]. Biznes-navigator. Vol. 3. p. 173178. [in Ukrainian].

6. Romanyak G. M. Sutnist antykryzovogo upravlinnya pidpryyemstvom v umovax nestabilnogo rynkovogo seredovyshha. nbuv.gov.ua Retrieved from: http://nbuv.gov.ua/UJRN/Nz_2016_1_31. [in Ukrainian].

7. Sedikova I. O. (2018). Upravlinnya innovacijnoyu diyalnistyu pidpryyemstv kondyterskoyi galuzi. [Management of innovation activity of confectionery enterprises.]. Science visn. Uzhgorodskogo nacz. un-tu. International Economic Relations and the World Economy Series. Vol. 18, Is. 3. p. 55 - 59. [in Ukrainian].

8. Informacijnyj portal «Liga.net» (n.d.). liga.net. Retrieved from: https://www.liga.net/economics/infografica/kak-izmenilas-rasstanovka-sil-na-konditerskom-rynkeukrainy. [in Ukrainian]. 